\title{
Hypervalent iodine(III)-mediated decarboxylative acetoxylation at tertiary and benzylic carbon centers
}

\author{
Kensuke Kiyokawa*, Daichi Okumatsu and Satoshi Minakata*
}

\author{
Full Research Paper \\ Address: \\ Department of Applied Chemistry, Graduate School of Engineering, \\ Osaka University, 2-1 Yamadaoka, Suita, Osaka 565-0871, Japan \\ Email: \\ Kensuke Kiyokawa* - kiyokawa@chem.eng.osaka-u.ac.jp; \\ Satoshi Minakata* - minakata@chem.eng.osaka-u.ac.jp \\ * Corresponding author \\ Keywords: \\ acetoxylation; carboxylic acids; decarboxylation; hypervalent iodine; \\ iodine
}

Beilstein J. Org. Chem. 2018, 14, 1046-1050.

doi:10.3762/bjoc. 14.92

Received: 14 February 2018

Accepted: 27 April 2018

Published: 15 May 2018

This article is part of the Thematic Series "Hypervalent iodine chemistry in organic synthesis".

Guest Editor: T. Wirth

(C) 2018 Kiyokawa et al.; licensee Beilstein-Institut.

License and terms: see end of document.

\begin{abstract}
The decarboxylative acetoxylation of carboxylic acids using a combination of $\mathrm{PhI}(\mathrm{OAc})_{2}$ and $\mathrm{I}_{2}$ in a $\mathrm{CH}_{2} \mathrm{Cl}_{2} / \mathrm{AcOH}$ mixed solvent is reported. The reaction was successfully applied to two types of carboxylic acids containing an $\alpha$-quaternary and a benzylic carbon center under mild reaction conditions. The resulting acetates were readily converted into the corresponding alcohols by hydrolysis.
\end{abstract}

\section{Introduction}

The decarboxylative functionalization of carboxylic acids and the derivatives thereof is an important transformation in organic synthesis. In recent years, increasing efforts have been devoted to the development of decarboxylative transformations [1-13], especially through radical decarboxylation processes, allowing an easy access to valuable compounds from readily available carboxylic acids. However, despite these advances, the oxidative decarboxylation coupled with $\mathrm{C}-\mathrm{O}$ bond formation has received considerably less attention, even though it represents a promising strategy for the synthesis of valuable alcohol derivatives. One of the classical methods for the decarboxylative $\mathrm{C}-\mathrm{O}$ bond formation of aliphatic carboxylic acids involves the use of stoichiometric amounts of heavy metal oxidants under hightemperature conditions $[14,15]$. Because these oxidants are typically highly toxic, their use has remained limited in organic synthesis. Barton et al. reported on the development of a practical method for the decarboxylative hydroxylation using thiohydroxamate esters as substrates [16]. Although the method was applicable to a broader range of substrates, the preparation of the activated ester is an intrinsic drawback to this procedure. While more convenient and practical methods for decarboxylative oxygenation, in which carboxylic acids are directly used as a substrate, have recently emerged, these methods have limited substrate scope [17-20]. 
A seminal work on decarboxylative functionalization in which a combination of $\mathrm{PhI}(\mathrm{OAc})_{2}$ and molecular iodine $\left(\mathrm{I}_{2}\right)$ are used was reported by Suárez et al. [21]. The method features mild reaction conditions, simple operation, and the use of readily available and environmentally friendly oxidants. However, despite the great potential of this approach with respect to a decarboxylative $\mathrm{C}-\mathrm{O}$ bond-forming reaction, the oxidation system was only applied to reactions of uronic acids and $\alpha$-amino acids [22-24], and further applications have not been explored. We recently reported on the decarboxylative Rittertype amination of carboxylic acids containing an $\alpha$-quaternary carbon center using a combination of $\mathrm{PhI}(\mathrm{OAc})_{2}$ and $\mathrm{I}_{2}$ to produce the corresponding $\alpha$-tertiary amine derivatives (Scheme 1) [25]. Mechanistic investigations indicated that the reaction proceeds via the formation of an alkyl iodide and the corresponding iodine(III) species as key intermediates. In this context, we concluded that the use of such an oxidation system, combined with the judicious choice of solvent, would enable a decarboxylative $\mathrm{C}-\mathrm{O}$ bond forming reaction, namely acetoxylation, via the oxidative displacement of an iodine atom of the in situ generated alkyl iodide by $\mathrm{PhI}(\mathrm{OAc})_{2}$ [26]. Herein, we report on the decarboxylative acetoxylation of carboxylic acids that contain an $\alpha$-quaternary carbon center using $\mathrm{PhI}(\mathrm{OAc})_{2}$ and $\mathrm{I}_{2}$ in a $\mathrm{CH}_{2} \mathrm{Cl}_{2} / \mathrm{AcOH}$ mixed solvent (Scheme 1). In subsequent experiments, the method was also found to be applicable to the reaction of benzylic carboxylic acids. The acetates that were produced in the reaction were readily converted into the corresponding alcohols by hydrolysis.

\section{Results and Discussion}

We started our investigation by examining the decarboxylative acetoxylation of 3-(4-bromophenyl)-2,2-dimethylpropanoic acid (1a) using $\mathrm{PhI}(\mathrm{OAc})_{2}$ and $\mathrm{I}_{2}$ as oxidants. When the reaction was conducted in $\mathrm{AcOH}$, the corresponding acetate 2a was obtained in low yield, and substantial amounts of the starting material were recovered, even though the use of $\mathrm{AcOH}$ as the solvent would be expected to promote the acetoxylation (Table 1, entry 1). Other solvents were then screened in attempts to improve the yield of the acetate 2a. Halogenated solvents such as $\mathrm{CH}_{2} \mathrm{Cl}_{2}$, 1,2-dichloroethane, and chlorobenzene were found to be more effective in producing $\mathbf{2 a}$ in moderate yields (Table 1, entries 2-4). The use of nitromethane also resulted in an improved yield of $2 \mathrm{a}$ of $60 \%$ (Table 1, entry 5). Interestingly, screening of additional solvents revealed that a $\mathrm{CH}_{2} \mathrm{Cl}_{2} / \mathrm{AcOH}$ mixed solvent was suitable for this transformation, and a ratio of $1: 1(\mathrm{v} / \mathrm{v})$ was found to be optimal, with 2 a being produced in $73 \%$ yield (Table 1 , entries $6-8$ ). When the reaction was performed at a higher concentration, the yield of product remained the same (Table 1, entry 9). Increasing the amount of oxidants used had only a slight effect on the product yield, with $\mathbf{2 a}$ being

Table 1: Effect of solvents and reaction parameters on the decarboxylative acetoxylation. ${ }^{a}$

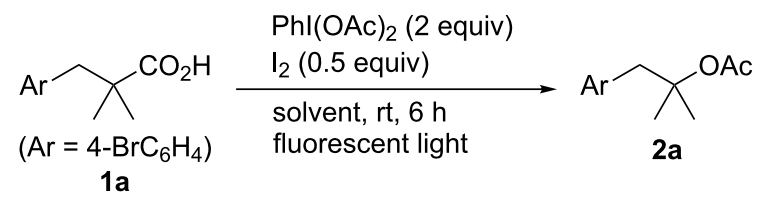

\begin{tabular}{lll}
\hline Entry & Solvent & ${\text { Yield }(\%)^{\mathrm{b}}}^{2}$ \\
\hline 1 & $\mathrm{AcOH}$ & 10 \\
2 & $\mathrm{CH}_{2} \mathrm{Cl}_{2}$ & 48 \\
3 & 1,2 -dichloroethane & 46 \\
4 & chlorobenzene & 42 \\
5 & $\mathrm{CH}_{3} \mathrm{NO}_{2}$ & 60 \\
6 & $\mathrm{CH}_{2} \mathrm{Cl}_{2} / \mathrm{AcOH}(1: 1)$ & 73 \\
7 & $\mathrm{CH}_{2} \mathrm{Cl}_{2} / \mathrm{AcOH}(3: 1)$ & 57 \\
8 & $\mathrm{CH}_{2} \mathrm{Cl}_{2} / \mathrm{AcOH}(1: 3)$ & 65 \\
$9^{\mathrm{c}}$ & $\mathrm{CH}_{2} \mathrm{Cl}_{2} / \mathrm{AcOH}(1: 1)$ & 74 \\
$10^{\mathrm{d}}$ & $\mathrm{CH}_{2} \mathrm{Cl}_{2} / \mathrm{AcOH}(1: 1)$ & 77 \\
$11^{\mathrm{e}}$ & $\mathrm{CH}_{2} \mathrm{Cl}_{2} / \mathrm{AcOH}(1: 1)$ & 75 \\
$12^{\mathrm{f}}$ & $\mathrm{CH}_{2} \mathrm{Cl}_{2} / \mathrm{AcOH}(1: 1)$ & 8 \\
$13^{\mathrm{g}}$ & $\mathrm{CH}_{2} \mathrm{Cl}_{2} / \mathrm{AcOH}(1: 1)$ & 0 \\
$14^{\mathrm{h}}$ & $\mathrm{CH}_{2} \mathrm{Cl}_{2} / \mathrm{AcOH}(1: 1)$ & $<5$ \\
\hline
\end{tabular}

aReactions were conducted on a $0.2 \mathrm{mmol}$ scale at a $0.2 \mathrm{M}$ concentration. Unless otherwise noted, reactions were performed on the benchtop with a fluorescent light on the ceiling. ${ }^{b}$ Determined by ${ }^{1} \mathrm{H}$ NMR analysis of the crude product using 1,1,2,2-tetrachloroethane as an internal standard. ${ }^{\mathrm{C}} \mathrm{The}$ reaction was conducted at a $0.4 \mathrm{M}$ concentration. ${ }^{\mathrm{d}} \mathrm{Phl}(\mathrm{OAc})_{2}$ ( 3 equiv) was used. ${ }^{\mathrm{e}} \mathrm{I}_{2}$ ( 1 equiv) was used. $\mathrm{f}_{2}$ (0.1 equiv) was used. 9The reaction was conducted without $\mathrm{I}_{2}$. ${ }^{\mathrm{h}}$ The reaction was conducted in the dark.

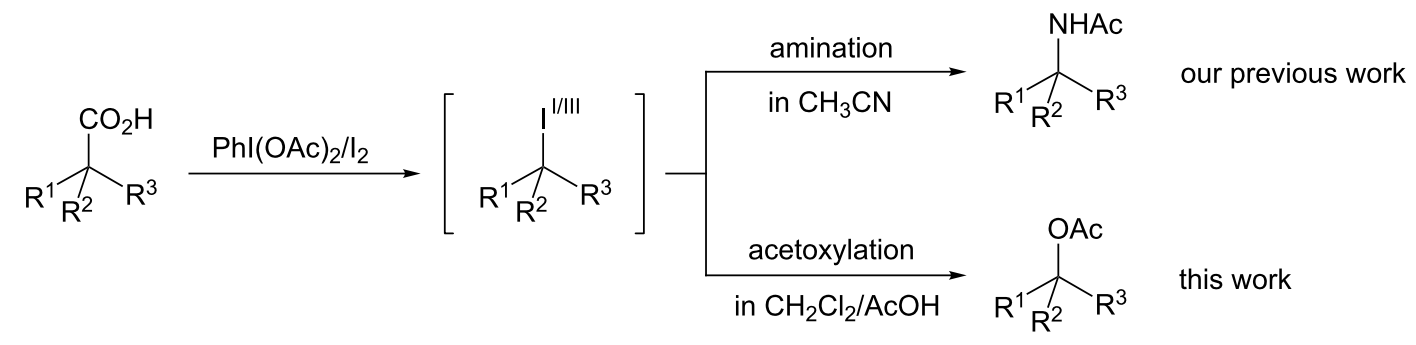


produced in $77 \%$ yield, when 3 equiv of $\mathrm{PhI}(\mathrm{OAc})_{2}$ were used (Table 1, entries 10 and 11). The reaction efficiency was significantly decreased with a catalytic amount of $\mathrm{I}_{2}$, and no reaction was observed in the absence of $\mathrm{I}_{2}$ (Table 1, entries 12 and 13). The reaction did not proceed in the dark, and most of the starting material was recovered (Table 1, entry 14). This result is consistent with a reaction proceeding via a light-induced radical decarboxylation process $[21,25]$.

We next explored the scope of the decarboxylative acetoxylation reaction (Scheme 2). A variety of carboxylic acids containing $\alpha$-quaternary carbon centers were efficiently converted into the corresponding acetates under mild reaction conditions [27]. Various functional groups, including bromo (2a and $\mathbf{2 f}$ ), fluoro (2b), carboxyl (2e), nitro (2g), and ester (2h) groups, were all well tolerated, providing the corresponding products in good yields. Notably, a carboxyl group on the phenyl ring was inert toward decarboxylation under the oxidation conditions used, allowing the acetate $2 \mathbf{e}$ to be successfully synthesized. The acetoxylation of a cyclohexane framework was also achieved, but the yield of the product $\mathbf{2} \mathbf{j}$ was somewhat lower than that of a non-cyclic 2i. Using this protocol, 1-adamantanecarboxylic acid was smoothly transformed into the corresponding acetate $\mathbf{2 k}$. In addition to the reaction with respect to tertiary carbon centers, the present method was successfully applied to benzylic carboxylic acid derivatives. For example, commercially available arylpropanoic acids, which include ibuprofen (1 $\mathbf{m})$ and loxoprofen (1n), underwent decarboxylative acetoxylation in a highly efficient manner. It should be noted that, although benzylic $\mathrm{C}-\mathrm{H}$ bonds are frequently incompatible with oxidative conditions, no products derived from benzylic $\mathrm{C}-\mathrm{H}$ oxidation were observed in this reaction system.

Hydrolysis of the acetates $\mathbf{2 c}$ and $\mathbf{2 m}$ under basic conditions furnished the corresponding alcohols $\mathbf{3 c}$ and $\mathbf{3 m}$, respectively, in nearly quantitative yields (Scheme 3 ). These results demonstrate that the present decarboxylative acetoxylation, followed by hydrolysis, offers an efficient and practical method for the synthesis of tertiary and benzylic alcohols.

The following experiments were performed in attempts to gain insights into the reaction pathway. Monitoring the reaction by

\footnotetext{
OAc

2a, $71 \%$<smiles>CC(=O)OC(C)(C)Cc1ccc(C(=O)O)cc1</smiles>

2e, $75 \%^{a, b}$

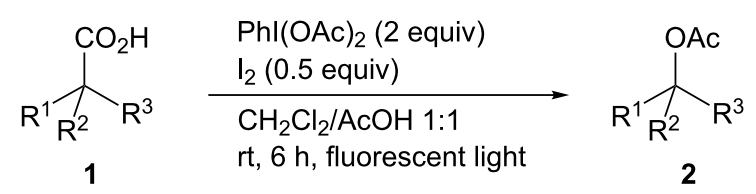<smiles>CC(=O)OC(C)(C)Cc1ccc(F)cc1</smiles>

2b, $70 \%$<smiles>CC(=O)OC(C)(C)Cc1ccccc1</smiles>

2c, $65 \%^{a}$<smiles>CC(=O)OC(C)(C)Cc1ccc(C)cc1</smiles>

2d, $66 \%$<smiles>CC(=O)OC(C)(C)Cc1cccc([N+](=O)[O-])c1</smiles>

2g, $68 \%$<smiles>COC(=O)CCC(C)(C)OC(C)=O</smiles>

2h, $42 \%^{a}$<smiles>CC(=O)OC(C)(C)Cc1ccccc1Br</smiles>

2f, $67 \%^{a, c}$<smiles>CC(=O)OC1(CCc2ccccc2)CCCCC1</smiles>

2j, 33\%a

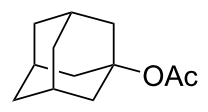

2k, $81 \%$<smiles>CC(=O)OC(C)c1ccccc1</smiles>

2I, $93 \%$<smiles>CC(=O)OC(C)c1ccc(CC(C)C)cc1</smiles>

2m, $93 \%$<smiles>CC(=O)OC(C)c1ccc(CC2CCCC2=O)cc1</smiles>

2n, $94 \%$ 


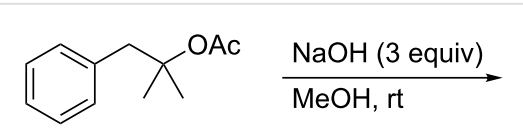

2c<smiles>CC(=O)OC(C)c1ccc(CC(C)C)cc1</smiles>

$2 \mathrm{~m}$

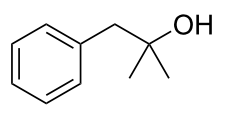

$3 c, 95 \%$
Scheme 3: Hydrolysis of acetates.

${ }^{1} \mathrm{H}$ NMR spectroscopy showed for the reaction of a mixture of 1 a with two equimolar amounts of $\mathrm{PhI}(\mathrm{OAc})_{2}$ in a $\mathrm{CD}_{2} \mathrm{Cl}_{2}$ / $\mathrm{CD}_{3} \mathrm{CO}_{2} \mathrm{D}(1: 1)$ mixed solvent the formation of a mixture of $\mathrm{PhI}(\mathrm{OAc})_{2}$ and $\mathbf{4 a}$ in a ratio of 11:1. This result indicates that ligand exchange between $1 \mathrm{a}$ and $\mathrm{PhI}(\mathrm{OAc})_{2}$ was suppressed due to the presence of an excess amount of acetic acid (Scheme 4a, see Supporting Information File 1 for details). Based on our previous work, we propose that the reaction pathway involves

a) reaction of $\mathrm{Phl}(\mathrm{OAc})_{2}$ with $\mathbf{1 a}$.

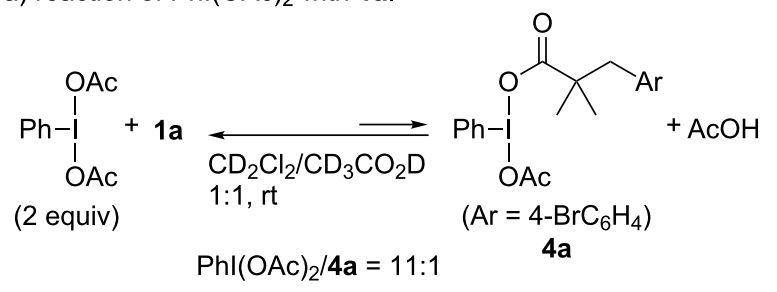

b) acetoxylation of alkyl iodide $\mathbf{5}$.<smiles>CC(C)(I)Cc1ccccc1</smiles>

5

\section{$\underset{\mathrm{Chl}(\mathrm{OAc})_{2} \text { (1 equiv) }}{\stackrel{\mathrm{CH}_{2} \mathrm{Cl}_{2} / \mathrm{AcOH} 1: 1}{\longrightarrow}}$} rt, $30 \mathrm{~min}$

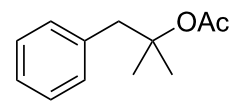

2c $82 \%$ $\left(0 \%\right.$ without $\left.\mathrm{Phl}(\mathrm{OAc})_{2}\right)$
Scheme 4: Mechanistic investigations. the formation of an alkyl iodide and the corresponding tertiary alkyl- $\lambda^{3}$-iodane species as intermediates [25]. To confirm the participation of these intermediates, the acetoxylation of a separately prepared sample of the tertiary alkyl iodide 5 was investigated. When 5 was treated with one equivalent of $\mathrm{PhI}(\mathrm{OAc})_{2}$ in a $\mathrm{CH}_{2} \mathrm{Cl}_{2} / \mathrm{AcOH}$ mixed solvent at room temperature, the acetoxylation proceeded efficiently to provide $2 \mathrm{c}$ (Scheme $4 \mathrm{~b}$ ). On the contrary, in the absence of $\mathrm{PhI}(\mathrm{OAc})_{2}$, no products were formed, and the starting material was recovered. These results strongly support a reaction pathway involving the formation of an alkyl iodide, which is oxidized by $\mathrm{PhI}(\mathrm{OAc})_{2}$ to the corresponding hypervalent iodine(III) species that then undergoes acetoxylation.

Based on the experimental results and our previous report [25], a proposed reaction pathway is depicted in Scheme 5. At the beginning of the reaction, $\mathrm{PhI}(\mathrm{OAc})_{2}$ predominantly exists rather than 4, as confirmed by NMR analysis. Therefore, in the initial stage, $\mathrm{PhI}(\mathrm{OAc})_{2}$ preferentially undergoes decomposition with $\mathrm{I}_{2}$ to provide acetyl hypoiodite (AcOI), which participates in the generation of $\mathrm{RCO}_{2} \mathrm{I}$ by reacting with a carboxylic acid 1. Meanwhile, $\mathrm{RCO}_{2} \mathrm{I}$ is directly generated along with AcOI when 4 reacts with $\mathrm{I}_{2}$. Subsequently, decarboxylative iodination of $\mathrm{RCO}_{2} \mathrm{I}$ under irradiation with visible light affords an alkyl iodide intermediate, which is then rapidly oxidized by the remaining $\mathrm{PhI}(\mathrm{OAc})_{2}$ to generate the corresponding alkyl$\lambda^{3}$-iodane ( $\left.\mathrm{RI}(\mathrm{OAc})_{2}\right)$, which then undergoes the acetoxylation to afford the acetate $\mathbf{2}$ along with the regeneration of AcOI [28].

\section{Conclusion}

In conclusion, the decarboxylative acetoxylation of carboxylic acids containing $\alpha$-quaternary and benzylic carbon centers was achieved by using a combination of $\mathrm{PhI}(\mathrm{OAc})_{2}$ and $\mathrm{I}_{2}$ in a $\mathrm{CH}_{2} \mathrm{Cl}_{2} / \mathrm{AcOH}$ mixed solvent. The key to the success of the reaction was the choice of a suitable solvent that enables an oxidative substitution of an alkyl iodide intermediate by $\mathrm{PhI}(\mathrm{OAc})_{2}$. This operationally simple method under metal-free and mild reaction conditions can be used to produce a variety of

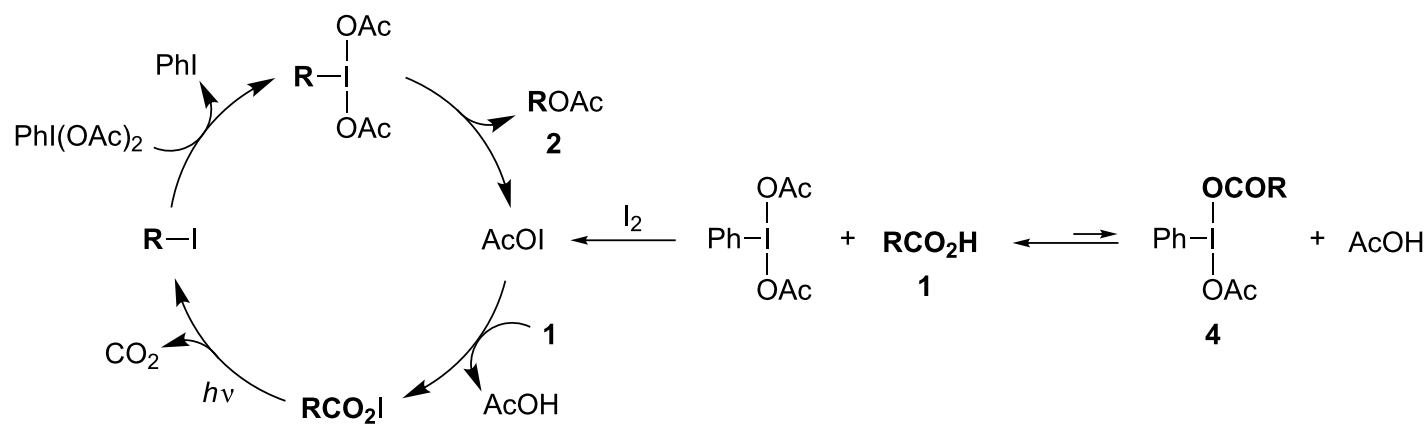


acetates, which can be efficiently transformed into tertiary and benzylic alcohols.

\section{Supporting Information}

\section{Supporting Information File 1}

Experimental procedures, characterization data, copies of the ${ }^{1} \mathrm{H},{ }^{13} \mathrm{C}$, and ${ }^{19} \mathrm{~F}$ NMR spectra.

[https://www.beilstein-journals.org/bjoc/content/ supplementary/1860-5397-14-92-S1.pdf]

\section{Acknowledgements}

This work was supported by JSPS KAKENHI Grant Number JP16K17868.

\section{ORCID ${ }^{\circledR}$ iDs}

Kensuke Kiyokawa - https://orcid.org/0000-0001-6124-2861 Satoshi Minakata - https://orcid.org/0000-0001-9619-445X

\section{References}

1. Twilton, J.; Le, C.; Zhang, P.; Shaw, M. H.; Evans, R. W.; MacMillan, D. W. C. Nat. Rev. Chem. 2017, 1, No. 0052. doi:10.1038/s41570-017-0052

2. Wei, Y.; Hu, P.; Zhang, M.; Su, W. Chem. Rev. 2017, 117, 8864-8907. doi:10.1021/acs.chemrev.6b00516

3. Li, Y.; Ge, L.; Muhammad, M. T.; Bao, H. Synthesis 2017, 49, 5263-5284. doi:10.1055/s-0036-1590935

4. Wang, Z.; Zhu, L.; Yin, F.; Su, Z.; Li, Z.; Li, C. J. Am. Chem. Soc. 2012, 134, 4258-4263. doi:10.1021/ja210361z

5. Yin, F.; Wang, Z.; Li, Z.; Li, C. J. Am. Chem. Soc. 2012, 134, 10401-10404. doi:10.1021/ja3048255

6. Liu, C.; Wang, X.; Li, Z.; Cui, L.; Li, C. J. Am. Chem. Soc. 2015, 137, 9820-9823. doi:10.1021/jacs.5b06821

7. Candish, L.; Teders, M.; Glorius, F. J. Am. Chem. Soc. 2017, 139, 7440-7443. doi:10.1021/jacs.7b03127

8. Perry, G. J. P.; Quibell, J. M.; Panigrahi, A.; Larrosa, I. J. Am. Chem. Soc. 2017, 139, 11527-11536. doi:10.1021/jacs.7b05155

9. Zhao, W.; Wurz, R. P.; Peters, J. C.; Fu, G. C. J. Am. Chem. Soc. 2017, 139, 12153-12156. doi:10.1021/jacs.7b07546

10. Wang, D.; Zhu, N.; Chen, P.; Lin, Z.; Liu, G. J. Am. Chem. Soc. 2017, 139, 15632-15635. doi:10.1021/jacs.7b09802

11. Li, C.; Wang, J.; Barton, L. M.; Yu, S.; Tian, M.; Peter, D. S.; Kumar, M.; Yu, A. W.; Johnson, K. A.; Chatterjee, A. K.; Yan, M.; Baran, P. S. Science 2017, 356, eaam7355. doi:10.1126/science.aam7355

12. Fawcett, A.; Pradeilles, J.; Wang, Y.; Mutsuga, T.; Myers, E. L.; Aggarwal, V. K. Science 2017, 357, 283-286. doi:10.1126/science.aan3679

13. Xue, W.; Oestreich, M. Angew. Chem., Int. Ed. 2017, 56, 11649-11652. doi:10.1002/anie.201706611

14. Mosher, W. A.; Kehr, C. L. J. Am. Chem. Soc. 1953, 75, 3172-3176. doi:10.1021/ja01109a039

15. Bacha, J. D.; Kochi, J. K. J. Org. Chem. 1968, 33, 83-93. doi:10.1021/jo01265a016
16. Barton, D. H. R.; Géro, S. D.; Holliday, P.; Quiclet-Sire, B.; Zard, S. Z. Tetrahedron 1998, 54, 6751-6756. doi:10.1016/S0040-4020(98)00337-8

17. Kiyokawa, K.; Yahata, S.; Kojima, T.; Minakata, S. Org. Lett. 2014, 16, 4646-4649. doi:10.1021/ol5022433

18. Xu, K.; Wang, Z.; Zhang, J.; Yu, L.; Tan, J. Org. Lett. 2015, 17, 4476-4478. doi:10.1021/acs.orglett.5b02142

19. Song, H.-T.; Ding, W.; Zhou, Q.-Q.; Liu, J.; Lu, L.-Q.; Xiao, W.-J. J. Org. Chem. 2016, 81, 7250-7255. doi:10.1021/acs.joc.6b01360

20. Yuan, Z.; Zhao, T.; Yu, T.; Wang, J.; Wei, H. Asian J. Org. Chem. 2017, 6, 262-264. doi:10.1002/ajoc.201600607

21. Concepción, J. I.; Francisco, C. G.; Freire, R.; Hernández, R.; Salazar, J. A.; Suárez, E. J. Org. Chem. 1986, 51, 402-404. doi:10.1021/jo00353a026

22. Francisco, C. G.; González, C. C.; Suárez, E. Tetrahedron Lett. 1997, 38, 4141-4144. doi:10.1016/S0040-4039(97)00805-8

23. Boto, A.; Hernández, R.; Suárez, E. Tetrahedron Lett. 1999, 40, 5945-5948. doi:10.1016/S0040-4039(99)01180-6

24. Boto, A.; Hernández, R.; Suárez, E. J. Org. Chem. 2000, 65, 4930-4937. doi:10.1021/jo000356t

25. Kiyokawa, K.; Watanabe, T.; Fra, L.; Kojima, T.; Minakata, S. J. Org. Chem. 2017, 82, 11711-11720. doi:10.1021/acs.joc.7b01202

26. Gallos, J.; Varvoglis, A. J. Chem. Soc., Perkin Trans. 11983 , 1999-2002. doi:10.1039/p19830001999

27. No product was observed when dodecanoic acid was used as a substrate.

28. The substitution by an acetate likely proceeds via a cationic intermediate. However, the detail of the mechanism as well as the stereochemical course of the step is not clear at this stage.

\section{License and Terms}

This is an Open Access article under the terms of the Creative Commons Attribution License (http://creativecommons.org/licenses/by/4.0), which permits unrestricted use, distribution, and reproduction in any medium, provided the original work is properly cited.

The license is subject to the Beilstein Journal of Organic Chemistry terms and conditions:

(https://www.beilstein-journals.org/bjoc)

The definitive version of this article is the electronic one which can be found at: doi:10.3762/bjoc. 14.92 